\title{
Impact of Land Use and Land Cover Changes on Surface Runoff and Sediment Yield in the Little Ruaha River Catchment
}

\author{
Nyemo A. Chilagane ${ }^{1 *}$, Japhet J. Kashaigili' ${ }^{1}$, Edmund Mutayoba², Paul Lyimo ${ }^{3}$, Pantaleo Munishi ${ }^{3}$, \\ Christine Tam ${ }^{4}$, Neil Burgess ${ }^{5}$
}

\author{
${ }^{1}$ Department of Forest Resources Assessment and Management, Sokoine University of Agriculture, Morogoro, Tanzania \\ ${ }^{2}$ Department of Water Supply and Irrigation Engineering, Water Institute, Dar es Salaam, Tanzania \\ ${ }^{3}$ Department of Ecosystem Sciences and Conservation, Sokoine University of Agriculture, Morogoro, Tanzania \\ ${ }^{4}$ WWF, Dar es Salaam, Tanzania \\ ${ }^{5}$ UN Environment World Conservation Monitoring Centre (UNEP-WCMC), Cambridge, UK \\ Email: *nchilagane@yahoo.com
}

How to cite this paper: Chilagane, N.A., Kashaigili, J.J., Mutayoba, E., Lyimo, P., Munishi, P., Tam, C. and Burgess, N. (2021) Impact of Land Use and Land Cover Changes on Surface Runoff and Sediment Yield in the Little Ruaha River Catchment. Open Journal of Modern Hydrology, 11, 54-74. https://doi.org/10.4236/ojmh.2021.113004

Received: May 22, 2021

Accepted: July 20, 2021

Published: July 23, 2021

Copyright $\odot 2021$ by author(s) and Scientific Research Publishing Inc. This work is licensed under the Creative Commons Attribution International License (CC BY 4.0).

http://creativecommons.org/licenses/by/4.0/

\begin{abstract}
Little Ruaha River catchment $\left(6370 \mathrm{Km}^{2}\right)$ in the Southern Agricultural Growth Corridor of Tanzania (SAGCOT), is one of the country's most significant waterways due to its ecological composition and economic value. Regardless of its ecological and economical value, the regional hydrologic condition has been tremendously affected due to land uses alteration, influenced by different socio-economic factors. This study aimed to understand the associated impacts of the present Land Use Land Cover (LULC) change on the surface runoff and sediment yield in the Little Ruaha River Catchment. Hydrological modelling using Soil and Water Assessment Tool (SWAT Model) was done to quantify the impact of land use and land cover dynamics on catchment water balance and sediment loads. The calibration and validation of the SWAT model were performed using sequential uncertainty fitting (SUFI-2). The results showed that, for the given LULC change, the average annual surface runoff increased by $2.78 \mathrm{~mm}$ while average annual total sediment loading increased by $3.56 \mathrm{t} / \mathrm{ha}$, the average annual base flow decreased by $2.68 \mathrm{~mm}$, ground water shallow aquifer recharge decreased from $2.97 \mathrm{~mm}$ and a slight decrease in average annual ground water deep aquifer recharge by $0.14 \mathrm{~mm}$. The model predicts that in the future, there will be a further increase in both surface runoff and sediment load. Such changes, increased runoff generation and sediment yield with decreased base flow have implications on the sustenance flow regimes particularly the observed reduced dry season river flow of the Little Ruaha River, which in turn cause adverse impacts to the biotic component of
\end{abstract}


the ecosystem, reduced water storage and energy production at Mtera Hydroelectrical dam also increasing the chances of flooding at some times of the year. The study recommends land use planning at the village level, and conservation agricultural practices to ameliorate the current situation. Developing multidisciplinary approaches for integrated catchment management is the key to the sustainability of Little Ruaha River catchment.

\section{Keywords}

Land Cover, Land Use, Sediment Loading, Surface Runoff, SWAT Model

\section{Introduction}

Land Use and Land Cover (LULC) are the important components of the terrestrial ecosystem that influence geomorphological, ecological and hydrological processes [1]. The changes in LULC call for special attention since humans have been modifying land to obtain food and other essentials for thousands of years, but current rates, extents and intensities of changes are far greater now compared to historically [2]. Day-to-day anthropogenic activities including expansion of agriculture, urbanization and deforestation activities have resulted in temporal and spatial changes in LULC which are argued to have contributed to change in hydrological regimes of many rivers and wetlands [3]. For instance, the conversion of tropical forest to grassland disrupts the hydrological cycle of a drainage basin, by altering the water yield of the area [4]. LULC change, particularly natural forest alteration, makes soils vulnerable to a massive increase in wind and water soil erosion, particularly on steep topography. When accompanied by fire, pollutants to the atmosphere are also released. Soil erosion over time may also cause damage to the land suitability for future farming, and releases a huge amount of phosphorus, nitrogen, and sediments to aquatic ecosystems, causing multiple harmful impacts of sedimentation and eutrophication.

The Little Ruaha River catchment in Tanzania, is one of the country's most significant waterways [5]. It provides irrigation and domestic fresh water services for many residents in the Southern Agricultural Growth Corridor of Tanzania (SAGCOT) specifically in Ihemi cluster. Furthermore, it is the main source of water during the dry season, and so is vital for the ecology of the downstream Ruaha National Park. Additionally, the catchment contributes about $18 \%$ of flows to the Mtera Dam [6], which is an important source of hydro-electric power and the largest reservoir in Tanzania, with a surface area of $600 \mathrm{~km}^{2}$ at the highest regulated water level. Despite its ecological and economical value, the regional hydrologic condition has been tremendously affected [7] due to LULC alteration [8]. However, there is a general understanding that the changes in catchment hydrology, occur mainly due to alteration in interception, infiltration, evapotranspiration and ground water recharge which are linked to LULC changes [9]. Estimating the effects of LULC changes on the hydrological response of Little 
Ruaha River Catchment remains very important for integrated management and conservation strategies. A number of studies have been carried out in the LRRC, nonetheless, most of these studies have not focused on quantifying the contribution of LULC change on the hydrological components of the catchment. Thus, a gap exists in up-to-date information regarding the effects of LULC changes on stream flow and sediment yield. The amount of sediments generated from LULC changes in the catchment as well as the contribution of individual land covers to the major hydrological components of the LRRC are not clear.

This study employed the Soil and Water Assessment Tool (SWAT), a regional scale hydrological model, to simulate the impacts of LULC changes on the hydrological response of the LRRC. There are lots of evidences for the application of SWAT Model for hydrological response modeling under different land uses and related studies. Many studies [9]-[16] have applied the SWAT model to simulate the impacts of land use/cover changes on the hydrological ecosystem and shown successful results.

\section{Materials and Methods}

\subsection{Study Location}

Little Ruaha River is a tributary of the Great Ruaha River (GRR) that joins GRR just after the Ruaha National Park [17]. Little Ruaha River Catchment (Figure 1), is located in the Southern Highlands of Tanzania, within Ihemi Cluster, one of the six priority clusters for agricultural development within the Southern Agricultural Growth Corridor of Tanzania (SAGCOT), which covers a larger part of Iringa and Njombe regions. The catchment has an estimated area of 6370 $\mathrm{km}^{2}$ draining from Mafinga, Mufindi, Kilolo, Iringa municipal and Iringa districts in Iringa Region [18].

Geographically, the catchment lies between longitudes $35^{\circ} 2^{\prime} \mathrm{E}$ and $35^{\circ} 36^{\prime} \mathrm{E}$ and, latitudes $7^{\circ} 11^{\prime} \mathrm{S}$ and $8^{\circ} 36^{\prime} \mathrm{S}$. The region's climate is unique in its heterogeneity, varying between the bimodal and unimodal rainfall patterns, with annual rainfall ranging from $600 \mathrm{~mm}$ in the lowlands to $1600 \mathrm{~mm}$ in the highlands which in turn results in diverse land uses [8]. The mean annual temperature varies with altitude from about $18^{\circ} \mathrm{C}$ at high altitudes to about $28^{\circ} \mathrm{C}$ at the lower altitudes. Elevation ranges from $698 \mathrm{~m}$ to above $2300 \mathrm{~m}$ above mean sea level. Dominant soils in the area include Cambisols, Fluvisols, Leptosols, Lixisols, Nitisols and Solonetz.

\subsection{Model Description}

The SWAT model is a continuous, long term, physical based distributed model developed by Agricultural Research Services of the United States Department of Agriculture to predict the impact of land management practices on water, sediment, and agriculture chemical yields in large and complex watersheds with varying soil, land use, and management conditions over long periods of time [19]. It operates on a daily time step and is considered to be the most suitable model 

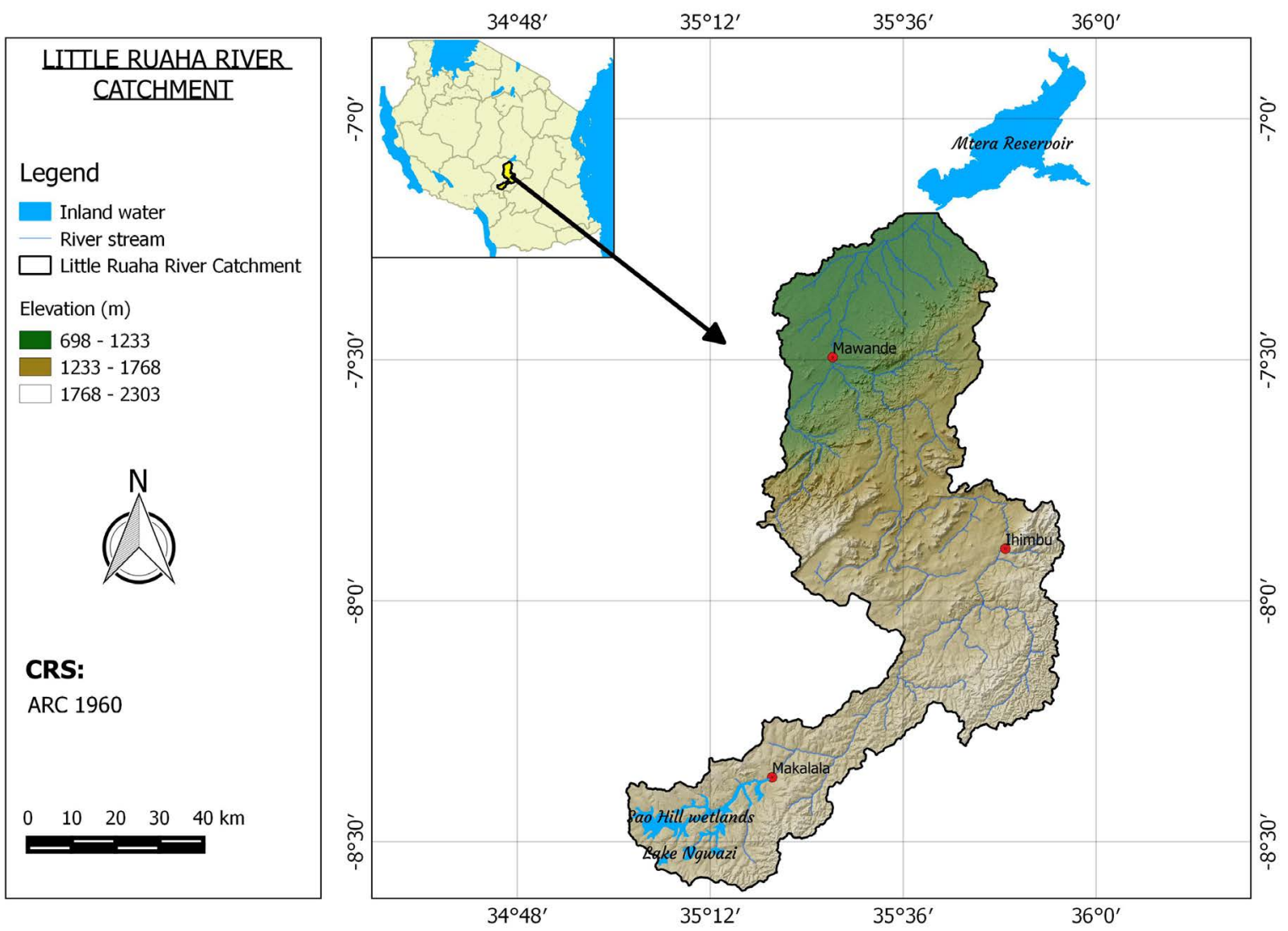

Figure 1. Little Ruaha River catchment.

to predict the impact of land use and management on water, sediment, and agricultural chemical yields in ungauged watersheds [20]. The model is capable of integrating different remote sensed spatial data and ground observation data sets (soil, land cover, weather data) describing the land surface to calculate the basin hydrologic water cycle [21], thus making it versatile in the area of watershed management and water resource planning [9]. The model is very useful because it has weather engine to generate the precipitation within an un-gauged watershed based on stochastic and probabilistic methods [21]. The basic operational of the model is the Hydrological Response Units (HRUs); the fundamental spatial unit that consist of homogeneous land use, management, topographical, and soil characteristics upon which SWAT simulates the water balance is the base of hydrologic cycle simulation in SWAT. Further reading on the SWAT model is accessed to the online resource at http://swat.tamu.edu/ and https://www.card.iastate.edu/swat articles/.

\subsection{SWAT Model Inputs}

SWAT model used in this study was built on QGIS 2.6.1 interface. The inputs data collected to set up the model includes spatial data, hydrological data and meteorological data. Spatial data includes $30 \mathrm{~m}$ resolution digital elevation model (DEM) downloaded from NASA (https://reverb.echo.nasa.gov). The digital 
LULC map (Figure 2) of the study area for 1990, 2015 and 2040 obtained from LULC change analysis reported by [22], mapped based on Landsat TM for 1990 and Landsat OLI for 2015 (http://earthexplorer.usgs.gov). Land use/land cover for the year 2040 was projected based on CA-Markov chain analysis. The Markov model is a theory based on the process of the formation of Markov random process systems for the prediction and optimal control theory method [23]. It tends to treat land use change as a stochastic process by assuming that rates of change between land use types are more or less constant from one period to the next.

Meteorological data comprised time series rainfall, relative humidity, solar radiation, wind speed and minimum and maximum temperature data for the period of 1976 to 2012, obtained from Tanzania Meteorological Agency and Rufiji Basin Water Office, Iringa. Hydrological data included time series river discharge, recorded from three different flow gauging stations, one located at the upper part of the catchment (Makalala station), one in the middle (Ihimbu station) and one in the lower part of the catchment (Mawande station). Soil data and information on related soil properties were obtained from the Food and Agriculture Organization (FAO) soil map [24].

\subsection{SWAT Model Calibration and Validation Process}

SWAT input parameters are process based and must be held within a realistic
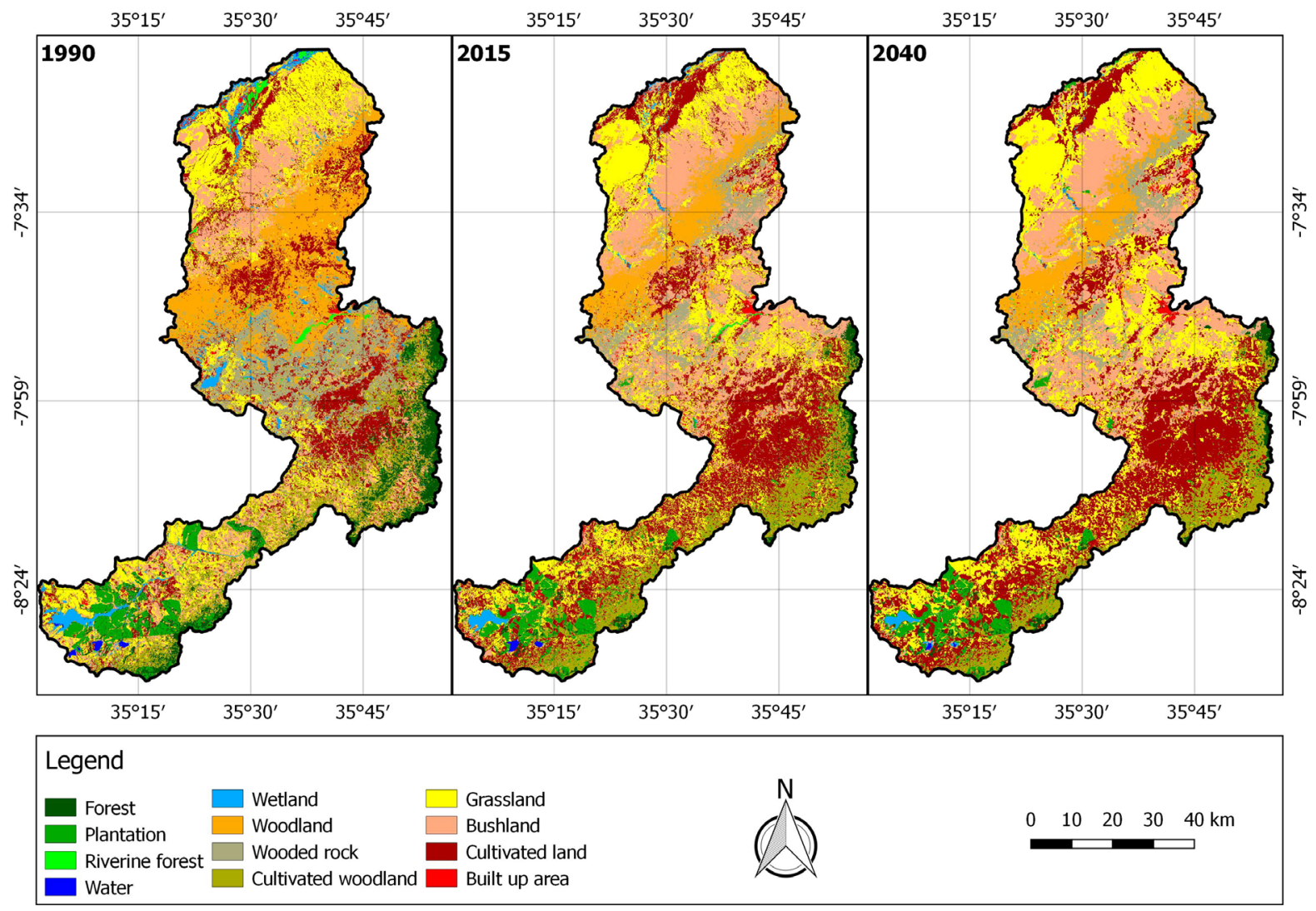

Figure 2. Land use/cover maps for LRRC year 1990, 2015 and 2040 (Source: Chilagane N, 2017). 
uncertainty range. Model Calibration is to adjust a set of parameters so that the model agreement is maximized with respect to a set of experimental data. It is the process of turning model parameters based on checking results against observations to ensure the same response over time [25]. Validation is the process of determining the degree to which a model is an accurate representation of the real world from the perspective of the intended uses of the model [26]. Calibration and Validation process in SWAT model involves three steps which are Sensitivity and Uncertainty Analysis, Model Calibration and Model Validation.

\subsubsection{Sensitivity Analysis}

To understand how closely the model simulates the hydrological processes within a watershed, it is critical to examine the influence of different parameters. Sensitivity analysis is the computation of the most sensitive parameters for a given watershed. In this study a sensitivity analysis was conducted using the Sequential Uncertainty Fitting (SUFI-2) within the SWAT-CUP [27]. The advantage of using SWAT-CUP relies on the possibility of using different kinds of parameters including those responsible for surface runoff, water quality parameters, crop, parameters, crop rotation and management parameters, and weather generator parameters [21].

\subsubsection{Model Calibration and Validation}

Calibration is an effort to better parameterize a model to a given set of local conditions, thereby reducing the prediction uncertainty and validation is the process of determining the degree to which a model is an accurate representation of the real world from the perspective of the intended uses of the model [26]. Model calibration and validation were performed by using the Sequential Uncertainty Fitting (SUFI-2) within the SWAT-CUP [27].

Calibration and validated were conducted using monthly flow data for the period 1990-2000 and 2001-2010 respectively, using data recorded from three different flow gauging stations, one located at the upper part of the catchment (Makalala station), one in the middle (Ihimbu station) and one in the lower part of the catchment (Mawande station). Five years prior to 1990 were used as a warm up period to provide steady-state condition and mitigate unknown initial conditions to the model. The model performance was assessed based on four objective functions namely, Nash-Sutcliffe Efficiency (NSE), Coefficient of determination $\left(\mathrm{R}^{2}\right)$, Probability bias (PBIAS) and Root mean square error (RSR). The general performance rating statistics for NSE, $\mathrm{R}^{2}$, RSR and PBIAS (Table 1)

Table 1. Recommended objective function statistics for monthly step.

\begin{tabular}{cc}
\hline Objective function & Performance rating for acceptable model \\
\hline Nash-Sutcliffe Efficiency (NSE) & $>0.5$ \\
Coefficient of determination ( ${ }^{2}$ ) & $>0.5$ \\
Root mean Square Error (RSR) & $\leq 0.70$ \\
Probability BIAS (PBIAS) & $\leq \pm 25 \%$ \\
\hline
\end{tabular}


as proposed by [28] and [9] were used to determine the performance of the model.

The Nash-Sutcliffe efficiency determines the relative magnitude of the residual variance compared to the measured data variance [29]. It used in the model to indicate how well the plot of observed versus simulated data fits the 1:1 line [28]. Nash-Sutcliffe efficiency range from $-\infty$ to 1 where efficiency of one $(E=1)$ corresponds to a perfect match of modeled discharge to the observed data, efficiency of zero $(E=0)$ indicates that the model predictions are as accurate as the mean of the observed data, and efficiency less than zero $(E<0)$ occurs when the observed mean is a better predictor than the model. Principally, the closer the model efficiency to 1 , the more accurate the model is. The NSE is calculated by:

$$
\mathrm{NSE}=1-\frac{\sum_{i}\left(Q_{i}-Q_{s}\right)^{2}}{\sum_{i}\left(Q_{i}-\bar{Q}_{i}\right)^{2}}
$$

Coefficient of determination $\left(\mathrm{R}^{2}\right)$ is a measure of the strength of the linear correlation between the predicted and observed variables. It ranges from 0 to 1 , with higher values indicating less error variance, and typically values greater than 0.5 are considered acceptable [30]. It is calculated as:

$$
\mathrm{R}^{2}=\left[\frac{\sum_{i}\left(Q_{i}-Q_{s}\right)\left(Q_{s}-\bar{Q}_{s}\right)}{\left(\sum_{i=1}^{n}\left(Q_{i}-\bar{Q}_{i}\right)\right)^{0.5}\left(\sum_{i=1}^{n}\left(Q_{s}-\bar{Q}_{s}\right)\right)^{0.5}}\right]^{2}
$$

Root mean square error-observed standard ration (RSR) is the measure of goodness of fit between observed and simulated time series data, is the ratio of the Root Mean Square Error (RMSE) and standard deviation of measured data. According to [31], RSR standardizes RMSE using the observations standard deviation, and it combines both an error index and the additional information recommended. It is commonly accepted that, the lower the RMSE the better the model performance. RSR is calculated as:

$$
\operatorname{RSR}=\frac{\operatorname{RMSE}}{\operatorname{STD}_{\text {obs }}}=\frac{\sqrt{\sum_{i=1}^{n}\left(Q_{i}-Q_{s}\right)^{2}}}{\sqrt{\sum_{i=1}^{n}\left(Q_{i}-\bar{Q}_{i}\right)^{2}}}
$$

Probability BIAS (PBIAS) is the measure of how much (in percentage) the simulated variable to be larger or smaller than their observed counterparts [32]. The optimum value of PBIAS is zero, where low magnitude values indicate better simulations, positive value indicated model underestimation and negative values indicated model overestimation [32]. It is calculated as:

$$
\text { PBIAS }=\frac{\sum_{i=1}^{n}\left(Q_{i}-Q_{s}\right)}{\sum_{i=1}^{n} Q_{i}} \times 100 \%
$$

where: $Q_{i}$ is observed variable (e.g., discharge), $Q_{s}$ is simulated variable and $\bar{Q}_{i}$ is the mean of observed variable, $\bar{Q}_{s}$ is the mean of simulated variable, RMSE is the root mean square error, STD $_{\text {obs }}$ is the standard deviation of the ob- 
served variable.

\subsection{Simulation Analysis}

To assess the impacts of LULC change on the hydrology of Little Ruaha River Catchment, the fix changing scenario was used [9] [33]. Under this scenario, the calibrated and validated model was used to simulate stream flows under changed land-use/cover condition for the year 1990/2015/2040, while maintaining the same weather data, meteorological data, soil data and digital elevation model. The influences of the land use land cover change on water resource and other hydrological components were quantified by comparing SWAT outputs for the two land use maps (1990/2015/2040). The differences between observed outputs represented the effects of land use and land cover changes on water resources in the catchment.

The SWAT model using the Modified Universal Soil Loss Equation (MUSLE) developed by [34] was used to simulate the sediment yield from the catchments [35]. The simulated sediment yield results for the time period 1990, 2015 and 2040 were compared, and the difference was deduced to reveal the impact of LULC change on sediment yields in Little Ruaha River Catchment.

\section{Results}

\subsection{Sensitive Parameters}

Table 2 shows list of parameters that were found to be most sensitive to flow prediction in the model. It was found that the runoff Soil Conservation Service runoff curve number (CN2) was the most sensitive parameter followed by Available Water Capacity of the Soil Layer (SOL_AWC), Threshold depth of water in the shallow aquifer required for return flow to occur (GWQWN), Groundwater Delay Time (GW_DELAY), Base Flow Alpha Factor (ALPHA_BF) and Soil Evaporation Compensation Factor (ESCO). These results are in agreement with the study reported by [11] that mentioned parameters are most sensitive to flow

Table 2. Most sensitive parameters and their fitted values.

\begin{tabular}{cccc}
\hline Rank & Parameter & Parameter definition & Fitted value \\
\hline 1 & CN2.mgt & SCS runoff curve number & -0.226087 \\
2 & SOL_AWC.sol & Available water capacity of the soil layer & -0.743945 \\
3 & GWQWN.gw & $\begin{array}{l}\text { Threshold depth of water in the shallow } \\
\text { aquifer required for return flow to occur }\end{array}$ & 1212.925537 \\
4 & GW_DELAY.gw & Groundwater delay & 146.182022 \\
5 & GW_REVAP & Groundwater "revap" coefficient & 0.037623 \\
6 & RCHRG_DP & Deep aquifer percolation fraction & 0.208973 \\
7 & ESCO.hru & Soil evaporation compensation factor & 0.321092 \\
8 & SURLAG & Surface runoff lag time & 6.335633 \\
9 & ALPHA_BF.gw & Baseflow alpha factor & 0.11056 \\
\hline
\end{tabular}


prediction. The most sensitive parameters were then considered for model calibration.

\subsection{Model Accuracy}

As mentioned, calibration was conducted in three sub-basins located in upstream, middle and downstream. The calibration process was done by comparing the simulated stream flows with the measured stream flows for each gauging station. Comparison of the results between the measured and calibrated stream flows show a good agreement with NSE, R ${ }^{2}$, RSR and PBIAS statistical values falling within the range of a satisfactory to good model (Table 3 ).

The observed mean monthly streamflow for the calibration period (1990-2000) in the Little Ruaha River at Makalala station was $4.40 \mathrm{~m}^{3} / \mathrm{s}$ while the simulated was $4.04 \mathrm{~m}^{3} / \mathrm{s}$. The difference was not significant for the downstream gauging stations as well, where the observed monthly stream flow was $16.80 \mathrm{~m}^{3} / \mathrm{s} \mathrm{com-}$ pared to the simulated $15.26 \mathrm{~m}^{3} / \mathrm{s}$ at Ihimbu station and at Mawande station observed monthly stream flow was $32.50 \mathrm{~m}^{3} / \mathrm{s}$ while simulated was $28.23 \mathrm{~m}^{3} / \mathrm{s}$.

Results for the validation period (2001-2010) show that the observed mean monthly stream flow was $4.25 \mathrm{~m}^{3} / \mathrm{s}$ and simulated mean monthly flow was 3.89 $\mathrm{m}^{3} / \mathrm{s}$ for Makalala gauging station, observed mean monthly flow of $16.06 \mathrm{~m}^{3} / \mathrm{s}$ and simulated mean monthly stream flow of $14.38 \mathrm{~m}^{3} / \mathrm{s}$ at Ihimbu station and observed mean daily stream flow of $28.46 \mathrm{~m}^{3} / \mathrm{s}$ with simulated mean monthly flow of $26.20 \mathrm{~m}^{3} / \mathrm{s}$ for Mawande gauging station. Figure 3 and Figure 4 below shows comparison of measure and simulated stream flow during model calibration and validation.

\subsection{Land Use Land Cover Change Analysis}

Results (Appendix 1 and Appendix 2) indicate that land use and land cover change between 1990 and 2015 and the projected land use/cover for the year 2040 as reported by [22]. The report detailed the decrease in forest, riverine forest, water, wetland and woodland by $60 \%, 81.58 \%, 62.50 \%, 70.65 \%$, and $46.62 \%$ respectively, while plantation, grassland, bushland, cultivated land and built up area increased by $17.71 \%, 25.27 \%, 43.90 \%, 34.36 \%$ and $46.31 \%$ respectively between 1990 and 2015.

Table 3. Evaluation statistics for calibration and validation.

\begin{tabular}{|c|c|c|c|c|c|c|c|c|c|c|c|c|}
\hline \multirow[b]{2}{*}{ Flow Station } & \multicolumn{4}{|c|}{ Calibration } & \multicolumn{4}{|c|}{ Validation } & \multicolumn{2}{|c|}{ Calibration } & \multicolumn{2}{|c|}{ Validation } \\
\hline & NSE & $\mathbf{R}^{2}$ & RSR & PBIAS & NSE & $\mathbf{R}^{2}$ & RSR & PBIAS & $\begin{array}{c}\text { Ob-flow } \\
\left(\mathrm{m}^{3} / \mathrm{s}\right)\end{array}$ & $\begin{array}{c}\text { Sim-flow } \\
\left(\mathrm{m}^{3} / \mathrm{s}\right)\end{array}$ & $\begin{array}{c}\text { Ob-flow } \\
\left(\mathrm{m}^{3} / \mathrm{s}\right)\end{array}$ & $\begin{array}{c}\text { Sim-flow } \\
\left(\mathrm{m}^{3} / \mathrm{s}\right)\end{array}$ \\
\hline Makalala & 0.56 & 0.57 & 0.66 & -5.9 & 0.50 & 0.51 & 0.71 & 8.5 & 4.40 & 4.04 & 4.25 & 3.89 \\
\hline Ihimbu & 0.58 & 0.60 & 0.65 & 9.1 & 0.44 & 0.55 & 0.75 & 21.6 & 16.80 & 15.26 & 16.06 & 14.38 \\
\hline Mawande & 0.64 & 0.65 & 0.60 & -15.1 & 0.64 & 0.65 & 0.60 & -8.6 & 32.50 & 28.23 & 28.46 & 26.20 \\
\hline
\end{tabular}

Ob-flow; Observed flow; Sim-flow; Simulated flow. 


\subsection{Impacts of Land Use/Cover Change on Water and Sediment Yields}

Table 4 below shows the annual averages hydrological summary for the Little Ruaha river sub-catchment under changing land use/cover. From the model, the change of land use/cover has contributed to the increase in average annual surface runoff by $2.78 \mathrm{~mm}$ and decrease in average annual base flow by $2.63 \mathrm{~mm}$. Water percolation to soil profile decreased by $2.64 \mathrm{~mm}$, ground water contribution

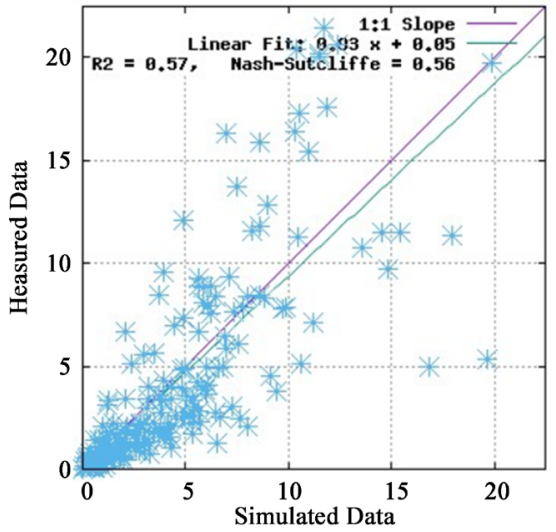

(a)

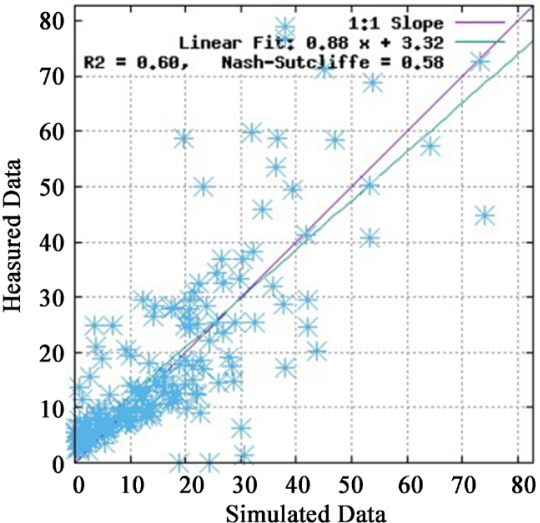

(b)

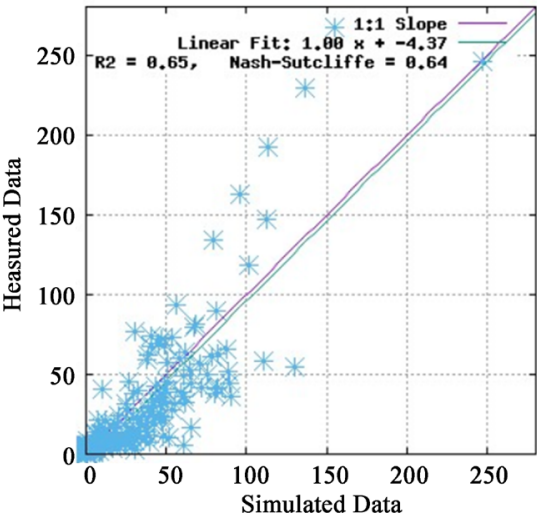

(c)

Figure 3. Comparison of measured and simulated stream flow during model calibration for (a) Makalala; (b) Ihimbu; (c) Mawande.

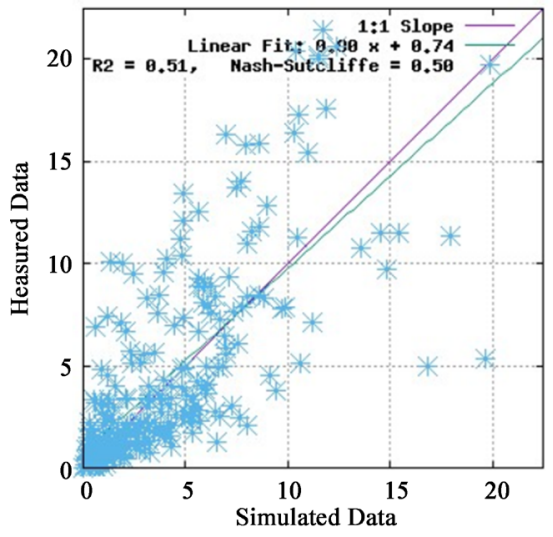

(a)

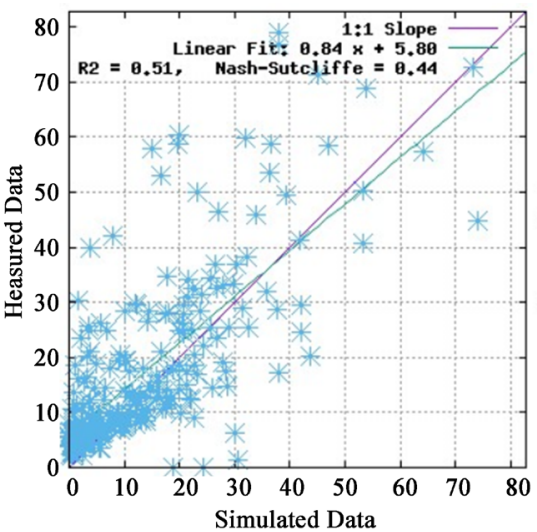

(b)

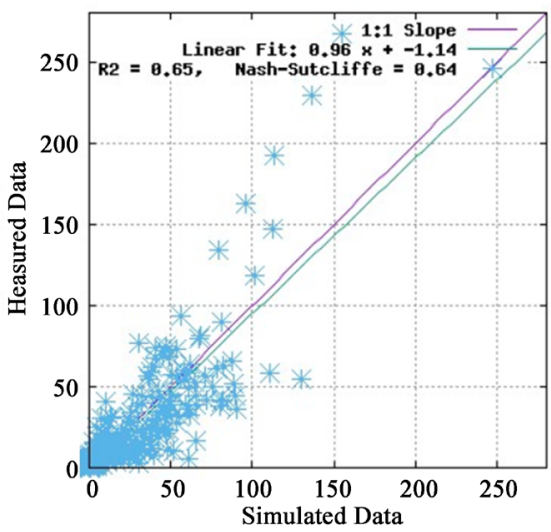

(c)

Figure 4. Comparison of measured and simulated stream flow during model validation for (a) Makalala; (b) Ihimbu; (c) Mawande.

Table 4. Annual average hydrological summary for the watershed.

\begin{tabular}{ccccccccc}
\hline Year & SURQ & PERCQ & GWQ & $\begin{array}{c}\text { Shall } \\
\text { AQ }\end{array}$ & $\begin{array}{c}\text { Deep } \\
\text { AQ }\end{array}$ & ET & $\begin{array}{c}\text { Water } \\
\text { Yield }(\mathrm{mm})\end{array}$ & $\begin{array}{c}\text { Sediment } \\
\text { Yield (t/h) }\end{array}$ \\
\hline 1990 & 45.83 & 346.03 & 351.24 & 297.97 & 17.66 & 272.4 & 375.52 & 9.397 \\
2015 & 48.61 & 343.4 & 348.56 & 295.42 & 17.52 & 272 & 375.74 & 12.958 \\
Change & 2.78 & -2.63 & -2.68 & -2.55 & -0.14 & -0.4 & 0.22 & 3.561 \\
\hline
\end{tabular}

SURQ: Surface runoff contribution from stream flow from HRU (mm); PERCQ: Water percolation past bottom of soil profile (mm); GWQ: Ground water contribution to stream in watershed on day, month, year $(\mathrm{mm})$; SHALL AQ: Ground water contribution to shallow aquifer $(\mathrm{mm})$; DEEP AQ: Ground water contribution to deep aquifer $(\mathrm{mm})$; ET: Actual evapo-transpiration in watershed $(\mathrm{mm})$. 
to shallow and deep aquifer decreased by $2.55 \mathrm{~mm}$ and $0.14 \mathrm{~mm}$ respectively. Actual evapotranspiration decreased by $0.4 \mathrm{~mm}$. The average annual water yields to stream flow and sediment yield from Hydrological Response Unit (HRU) in watershed has increased by $0.22 \mathrm{~mm}$ and $3.561 \mathrm{ton} / \mathrm{h}$ respectively.

SWAT simulations of the future scenarios showing expected changes in water and sediment yields in Little Ruaha River Catchment for the next 25 years from 2015 (Table 5). Results show the average annual surface runoff or overland flow will increase by $1.04 \mathrm{~mm}$, Water percolation to soil profile decreased by 0.81 $\mathrm{mm}$, ground water contribution to stream will decrease by 0.83 , ground water contribution to shallow and deep aquifer decreased by $0.83 \mathrm{~mm}$ and $0.04 \mathrm{~mm}$ respectively. Annual average actual evapotranspiration will decrease by $1 \mathrm{~mm}$. At the same time, the average annual water yield will increase by $0.12 \mathrm{~mm}$ which will raise soil loss from $12.958 \mathrm{t} / \mathrm{ha}$ to $13.797 \mathrm{t} / \mathrm{ha}$.

Furthermore, the model revealed the LULC changes have also impacted dry seasonal flow of Little Ruaha river. SWAT scenario revealed decline of average dry season flow (July-October) in three-gauge stations of Little Ruaha river namely Makalala (Upper), Ihimbu (Middle) and Mawande (lower) following LULC transformation (Figures 5-7). Dry season monthly averages at different land use scenario for Makalala, Ihimbu and Mawande gauge stations are represented in Tables 6-8 respectively.

Table 5. Annual average hydrological summary for the watershed for the year 2040 .

\begin{tabular}{ccccccccc}
\hline Year & SURQ & PERCQ & GWQ & $\begin{array}{c}\text { Shall } \\
\text { AQ }\end{array}$ & $\begin{array}{c}\text { Deep } \\
\text { AQ }\end{array}$ & ET & $\begin{array}{c}\text { Water } \\
\text { Yield (mm) }\end{array}$ & $\begin{array}{c}\text { Sediment Yield } \\
(\mathrm{t} / \mathrm{h})\end{array}$ \\
\hline 2015 & 48.61 & 343.4 & 348.56 & 295.42 & 17.52 & 272 & 375.74 & 12.958 \\
2040 & 49.65 & 342.59 & 347.73 & 294.6 & 17.48 & 271 & 375.86 & 13.797 \\
Change & 1.04 & -0.81 & -0.83 & -0.82 & -0.04 & -1 & 0.12 & 0.839 \\
\hline
\end{tabular}

SURQ: Surface runoff contribution from stream flow from HRU (mm); PERCQ: Water percolation past bottom of soil profile (mm); GWQ: Ground water contribution to stream in watershed on day, month, year $(\mathrm{mm})$; SHALL AQ: Ground water contribution to shallow aquifer (mm); DEEP AQ: Ground water contribution to deep aquifer ( $\mathrm{mm})$; ET: Actual evapo-transpiration in watershed ( $\mathrm{mm}$ ).

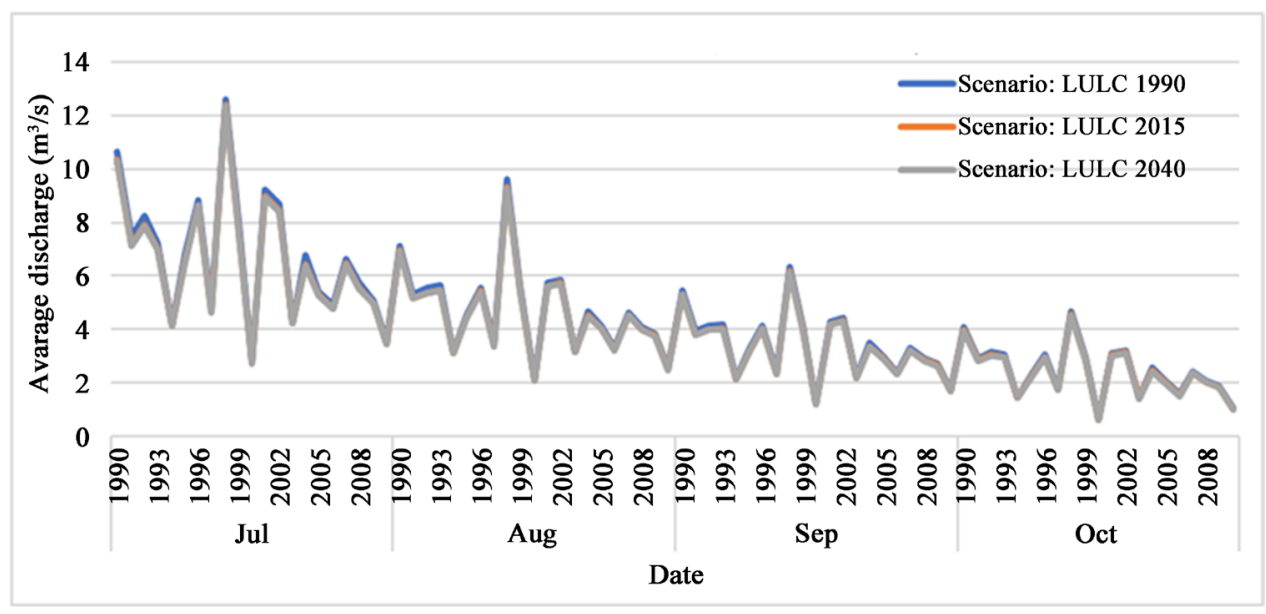

Figure 5. Dry season average discharge at Makalaka gauge station. 
Table 6. Dry season monthly averages at different land use scenarios for Makalala station.

\begin{tabular}{cccc}
\hline Month & $\begin{array}{c}\text { Average discharge } \\
\left(\mathrm{m}^{3} / \mathrm{s}\right)\end{array}$ & $\begin{array}{c}\text { Average discharge } \\
\left(\mathrm{m}^{3} / \mathrm{s}\right)\end{array}$ & $\begin{array}{c}\text { Average discharge } \\
\left(\mathrm{m}^{3} / \mathrm{s}\right)\end{array}$ \\
Scenario: LULC 1990 & Scenario: LULC 2015 & 6.53 \\
Jul & 6.76 & 6.57 & 4.61 \\
Aug & 4.74 & 4.63 & 3.31 \\
Sep & 3.41 & 3.33 & 2.37 \\
Oct & 2.45 & 2.38 & 4.20 \\
Total & 4.34 & 4.23 & \\
\hline
\end{tabular}

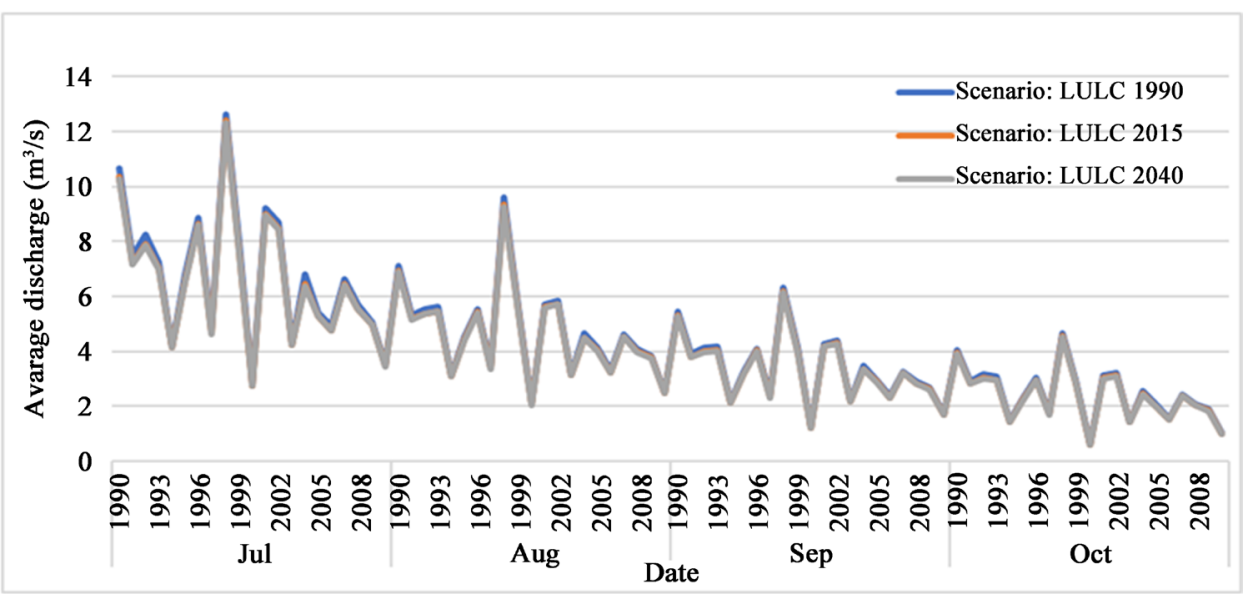

Figure 6. Dry season avarage discharge at Ihimbu gauge station.

Table 7. Dry season monthly averages at different land use scenarios for Ihimbu station.

\begin{tabular}{|c|c|c|c|}
\hline Month & $\begin{array}{c}\text { Average discharge } \\
\left(\mathrm{m}^{3} / \mathrm{s}\right)\end{array}$ & $\begin{array}{c}\text { Average discharge } \\
\left(\mathrm{m}^{3} / \mathrm{s}\right)\end{array}$ & $\begin{array}{c}\text { Average discharge } \\
\left(\mathrm{m}^{3} / \mathrm{s}\right) \\
\text { LULC } 2040\end{array}$ \\
\hline Jul. & 22.51 & 21.62 & 21.34 \\
\hline Aug. & 15.68 & 15.15 & 14.99 \\
\hline Sep. & 11.03 & 10.62 & 10.49 \\
\hline Oct. & 7.69 & 7.36 & 7.25 \\
\hline Total & 14.23 & 13.69 & 13.52 \\
\hline
\end{tabular}

\subsection{Contribution of Individual Land/Cover to the Surface Runoff and Sediment Yield}

The proportional contribution of individual LULC to surface runoff and sediment yield is summarized in Figure 8 below. Results found that cultivated woodland and cultivated land are the main contributors to both surface runoff and sediment yields followed by built up area which has high contribution to surface runoff but very little contributions to sediment yield. Forest, woodland and wetland were found to have very little contributions to sediment yield but showing a variation on their contribution to surface runoff. 
Figures 9(a)-(c) below shows the spatial annual means contribution to hydrologic component of the Little Ruaha river catchment.

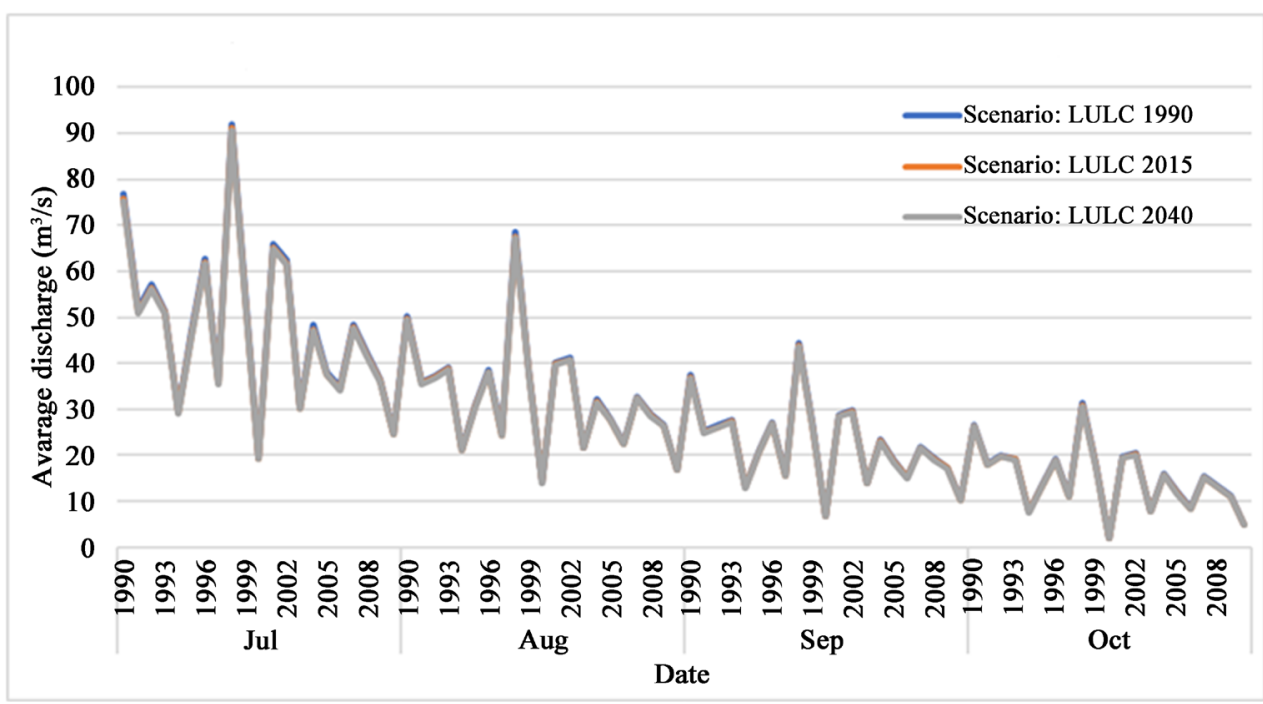

Figure 7. Dry season avarage discharge at Mawande gauge station.

Table 8. Dry season monthly averages at different land use scenarios for Mawande station.

\begin{tabular}{cccc}
\hline Month & $\begin{array}{c}\text { Average discharge } \\
\left(\mathrm{m}^{3} / \mathrm{s}\right)\end{array}$ & $\begin{array}{c}\text { Average discharge } \\
\left(\mathrm{m}^{3} / \mathrm{s}\right)\end{array}$ & $\begin{array}{c}\text { Average discharge } \\
\left(\mathrm{m}^{3} / \mathrm{s}\right)\end{array}$ \\
Scenario: LULC 1990 & Scenario: LULC 2015 & LULC 2040 \\
\hline Jul & 48.18 & 47.56 & 47.33 \\
Aug & 32.91 & 32.54 & 32.39 \\
Sep & 22.45 & 22.16 & 22.05 \\
Oct & 15.04 & 14.82 & 14.73 \\
Total & 29.64 & 29.27 & 29.12 \\
\hline
\end{tabular}

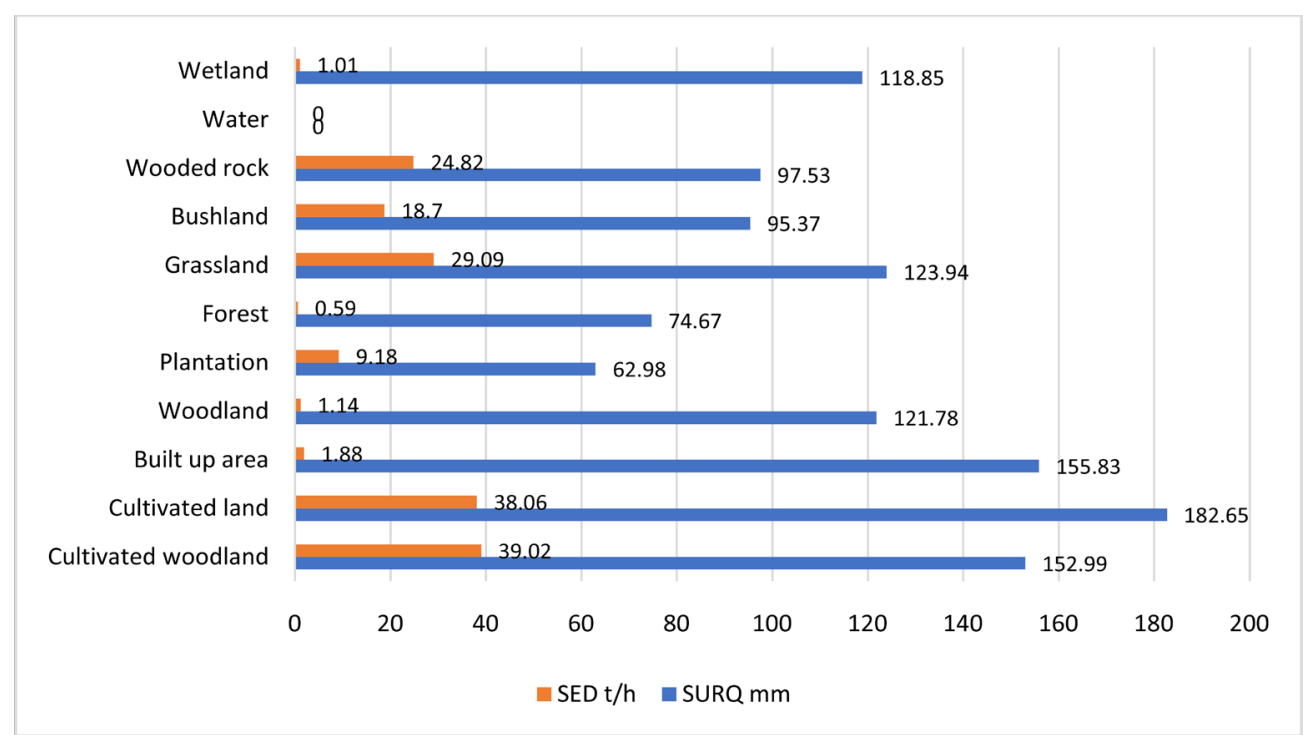

Figure 8. Contribution of individual land use/cover on surface runoff and sediment yield. 


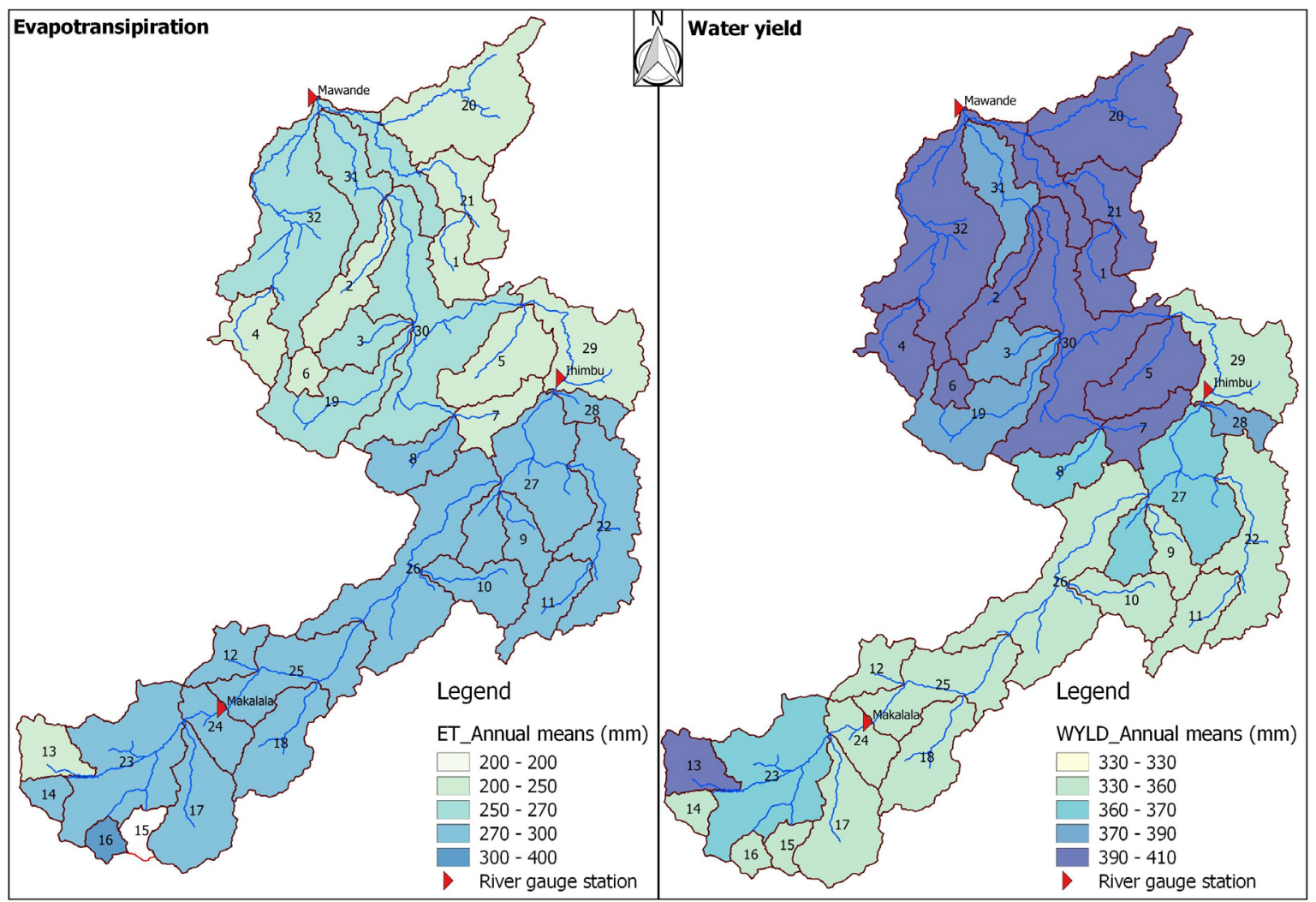

(a)

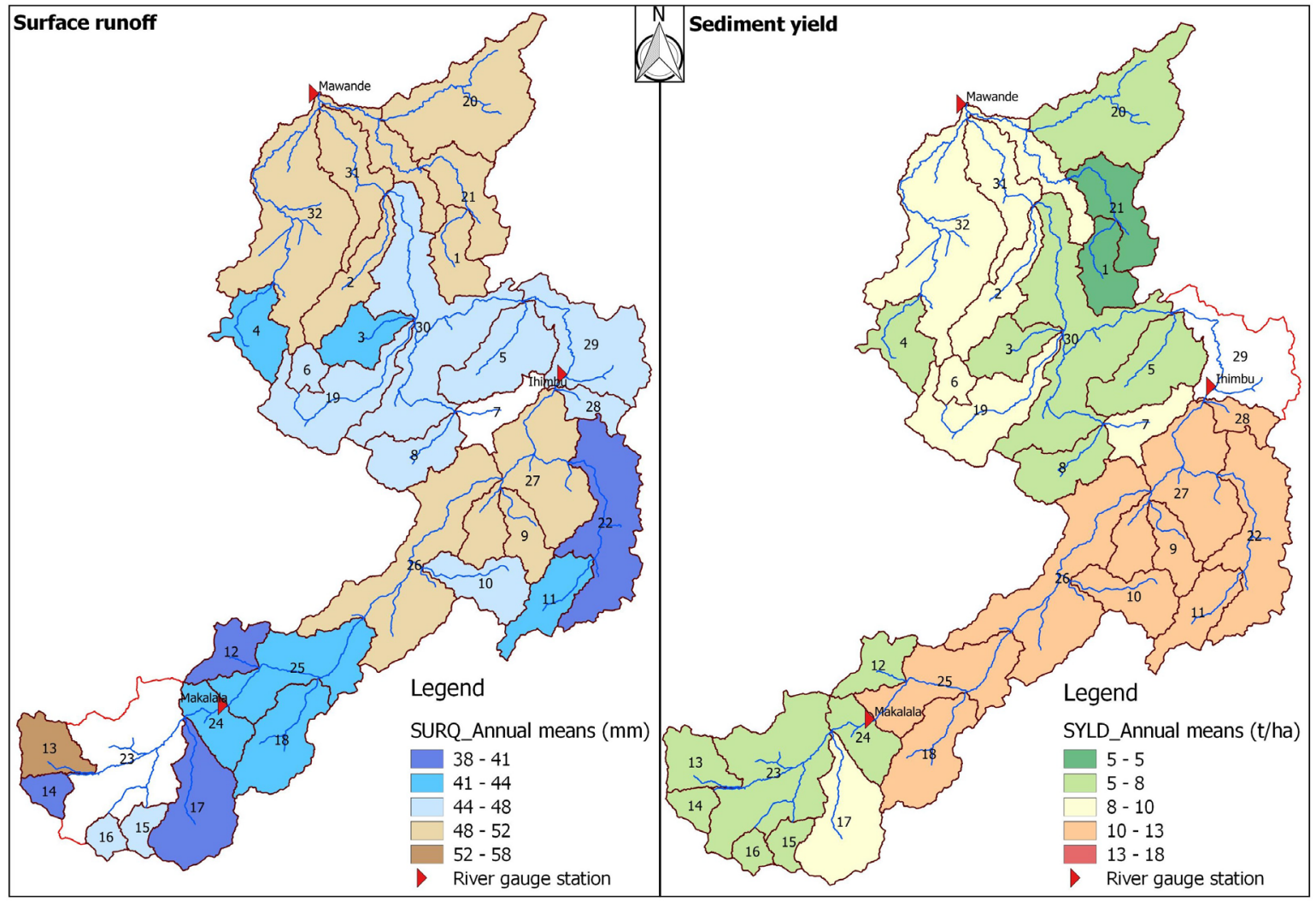

(b) 


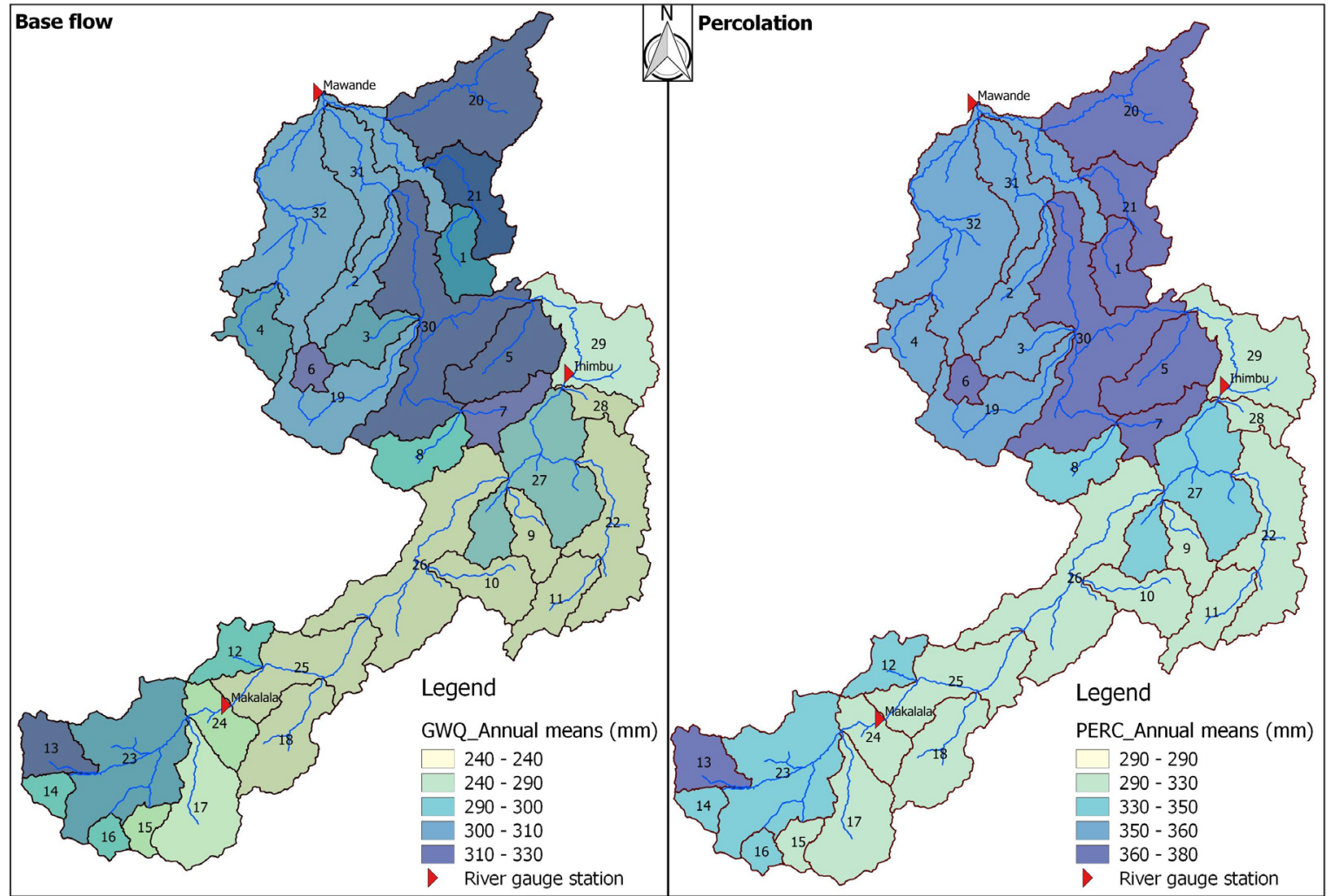

(c)

Figure 9. Subbasin contribution on hydrological component of the catchment.

\section{Discussion}

The study findings indicate that the change in the LULC has a significant impact on the hydrological response of Little Ruaha River Catchment. The expansions of agricultural activities and built-up areas are directly linked with increased water use for irrigation and domestic use. The land use changes, particularly, conversion of forest covers (natural forest, woodland and riverine forest) between 1990 and 2015, are associated with the increased runoff. Increase in storm runoff is mainly due to the reduced infiltration rate when forest is converted to other land uses [36] [37]. These changes in runoff generation are in agreement with the general knowledge that reducing forest cover decrease opportunity of infiltration which in turn leads into an increase in water yield due to increased surface runoff [38] [39], has reported that the increased water yield and surface runoff in the catchment bring environmental problems including soil erosion and siltation of water bodies. Furthermore, the decrease in base flow and evapotranspiration observed in the study is accompanied with the alteration of forest covers. This was highlighted in [40], as cited in [38] that forest cover removal decreases the opportunity of infiltration to the extent that surface flow exceeds the gain in base flow which results in diminished dry seasonal flow. Studies from Tanzania and other different countries have also shown the influence of land use changes on runoff generation [41] [42] [43]. According to this study, it is ap- 
parently clear that, land use and cover changes impact on the water yield and sediment yield and have implications on the sustenance flow regimes particularly dry season river flows which in turn cause adversely impacts not only to biotic component of ecosystem found within and outside the catchment but also hydropower generation.

It is also important noting that much of the planned development investments in the Ihemi Cluster including agriculture, tourism, and energy production depends much on the Little Ruaha River, therefore decrease in river flow can be a very challenging factor for agricultural development for small holders' farmers in the SAGCOT as well as tourism activities in the Ruaha Natinal park. Little Ruaha river is essential sources of surface water for wildlife during 'dry' seasons when rainfall is limited or absent, particularly for species whose resilience to water scarcity is low. The decreased flow in this river jeopardizes the survival of these wild animals especially during dry season which in turn have negative implication in tourism industry. Increase sediment generation represents a serious threat to the sustainability of Mtera hydropower. Sedimentation may affect the safety of dams and reduces energy production, storage, discharge capacity and flood attenuation capabilities which threaten security to downstream user.

\section{Conclusions}

This study has examined the impact of land use and land cover changes on hydrological response with a strong focus on water quantity and sediment yield in Little Ruaha River Catchment. The results indicate that changes in land use and land cover have a significant impact on the hydrological response of the catchment. An increase in sediment yield and surface runoff along with a decrease in base flow and lateral flow were directly associated with the transformation of land use and land cover in the catchment. Such changes, increased runoff generation and sediment yield with the decreased base flow have implications on the sustenance flow regimes particularly diminish dry season river flows, which in turn cause adverse impacts to a biotic component of the ecosystem and reduced water storage and energy production at Mtera Hydroelectrical dam.

Therefore, to ensure the sustainability of water resources in the Little Ruaha River Catchment, the study recommends the need for an appropriate intervention including implementation of sustainable land use planning at the village level, and conservation agriculture practices to ameliorate the current situation. According to the model results, it is necessary to prescribe appropriate soil and water conservation practices to all subbasins with high runoff and sediment generation identified in the model results (Figure 9(b)). Subsequent land development should avoid such areas because of the need to adequately protect them with appropriate conservation strategies.

\section{Acknowledgements}

The author acknowledges funding from the UK Research and Innovation's Global 
Challenges Research Fund (UKRI GCRF) through the Development Corridors Partnership project (project number: ES/P011500/1). Special thanks to Rufiji Basin Water Office, Iringa and Tanzania Meteorological Agency (TMA) for providing with necessary data for this work.

\section{Conflicts of Interest}

The authors declare no conflicts of interest regarding the publication of this paper.

\section{References}

[1] Githui, F., Gitau, W., Mutua, F. and Bauwens, W. (2009) Climate Change Impact on SWAT Simulated Streamflow in Western Kenya. International Journal of Climatology, 29, 1823-1834. https://doi.org/10.1002/joc.1828

[2] Ruddiman, W.F. (2003) The Anthropogenic Greenhouse Era Began Thousands of Years Ago. Climatic Change, 61, 261-293. https://doi.org/10.1023/B:CLIM.0000004577.17928.fa

[3] Rawat, J.S. and Manish, K. (2015) Monitoring Land Use/Cover Change Using Remote Sensing and GIS Techniques: A Case Study of Hawalbagh Block, District Almora, Uttarakhand, India. National Authority for Remote Sensing and Space Sciences. The Egyptian Journal of Remote Sensing and Space Sciences, 18, 77-84. https://doi.org/10.1016/j.ejrs.2015.02.002

[4] Sokile, C.S., Kashaigili, J.J. and Kadigi, R.M. (2003) Towards an Integrated Water Resource Management in Tanzania: The Role of Appropriate Institutional Framework in Rufiji Basin. Physics and Chemistry of the Earth, Parts A/B/C, 28, 1015-1023. https://doi.org/10.1016/j.pce.2003.08.043

[5] Kadigi, R.M., Kashaigili, J.J. and Mdoe, N.S. (2004) The Economics of Irrigated Paddy in Usangu Basin in Tanzania: Water Utilization, Productivity, Income and liveLihood Implications. Physics and Chemistry of the Earth, Parts $A / B / C, 29$, 1091-1100. https://doi.org/10.1016/j.pce.2004.08.010

[6] Kashaigili, J.J., Kadigi, R.M., Lankford, B.A., Mahoo, H.F. and Mashauri, D.A. (2005) Environmental Flows Allocation in River Basins: Exploring Allocation Challenges and Options in the Great Ruaha River Catchment in Tanzania. Physics and Chemistry of the Earth, Parts $A / B / C, 30,689-697$.

https://doi.org/10.1016/j.pce.2005.08.009

[7] Li, R.Q., Dong, M., Cui, J.Y., Zhang, L.L., Cui, Q.G. and He, W.M. (2007) Quantification of the Impact of Land-use Changes on Ecosystem Services: A Case Study in Pingbian County, China. Environmental Monitoring and Assessment, 128, 503-510. https://doi.org/10.1007/s10661-006-9344-0

[8] Milder, J.C., Buck, L.E., Hart, A.K., Scherr, S.J. and Shames, S.A. (2013) A Framework for Agriculture Green Growth: Greenprint for the Southern Agricultural Growth Corridor of Tanzania (SAGCOT). SAGCOT Centre, Dar es Salaam.

[9] Gyamfi, C., Ndambuki, J.M. and Salim, R.W. (2016) Hydrological Responses to Land Use/Cover Changes in the Olifants Basin, South Africa. Water, 8, 588. https://doi.org/10.3390/w8120588

[10] Ashagre, B.B., Platts, P.J., Njana, M., Burgess, N.D., Balmford, A., Turner, R.K. and Schaafsma, M. (2018) Integrated Modelling for Economic Valuation of the Role of Forests and Woodlands in Drinking Water Provision to Two African Cities. Ecosystem Services, 32, 50-61. https://doi.org/10.1016/j.ecoser.2018.05.004

[11] Mbungu, W.M. and Kashaigili, J.J. (2017) Assessing the Hydrology of a Data-Scarce 
Tropical Watershed Using the Soil and Water Assessment Tool: Case of the Little Ruaha River Watershed in Iringa, Tanzania. https://doi.org/10.4236/ojmh.2017.72004

[12] Welde, K. and Gebremariam, B. (2017) Effect of Land Use Land Cover Dynamics on Hydrological Response of Watershed: Case Study of Tekeze Dam Watershed, Northern Ethiopia. International Soil and Water Conservation Research, 5, 1-16. https://doi.org/10.1016/j.iswcr.2017.03.002

[13] Ndulue, E.L., Mbajiorgu, C.C., Ugwu, S.N., Ogwo, V. and Ogbu, K.N. (2015) Assessment of Land Use/Cover Impacts on Runoff and Sediment Yield Using Hydrologic Models: A Review. Journal of Ecology and the Natural Environment, 7, 46-55. https://doi.org/10.5897/JENE2014.0482

[14] Kimwaga, R.J., Mashauri, D.A., Bukirwa, F., Banadda, N., Wali, U.G., Nhapi, I. and Nansubuga, I. (2011) Modelling of Non-Point Source Pollution around Lake Victoria Using Swat Model: A Case of Simiyu Catchment Tanzania. The Open Environmental Engineering Journal, 4, 112-123. https://doi.org/10.2174/1874829501104010112

[15] Palamuleni, L.G. and Annegarn, H.J. (2011) Hydrological Response to Predicted Land Cover Change in the Upper Shire River Catchment, Malawi. International Journal of Environmental Research and Public Health, 36, 43-52. https://doi.org/10.1080/09709274.2011.11906416

[16] Ndomba, P., Mtalo, F. and Killingtveit, A. (2008) SWAT Model Application in a Data Scarce Tropical Complex Catchment in Tanzania. Physics and Chemistry of the Earth, Parts A/B/C, 33, 626-632. https://doi.org/10.1016/j.pce.2008.06.013

[17] Kashaigili, J.J., Mccartney, M. and Mahoo, H.F. (2007) Estimation of Environmental Flows in the Great Ruaha River Catchment, Tanzania. Physics and Chemistry of the Earth, Parts A/B/C, 32, 1007-1014. https://doi.org/10.1016/j.pce.2007.07.005

[18] Chilagane, N. (2017) Impacts of Land Use and Land Cover Changes on the Ecosystem Services of the Little Ruaha River Cachment, Tanzania. Dissertation of Awarding MSc Degree, Sokoine University of Agriculture, Morogoro, 89 p.

[19] Arnold, J.G., Srinivasan, R., Muttiah, R.S. and Williams, J.R. (1998) Large Area Hydrologic Modeling and Assessment Part 1: Model Development. Journal of American Water Resource Association, 34, 73-89. https://doi.org/10.1111/j.1752-1688.1998.tb05961.x

[20] Neitsch, S.L., Arnold, J.G., Kiniry, J.R. and Williams, J.R. (2001) Soil and Water Assessment Tool Version 2000-User's Manual. Grassland, Soil \& Water Research Laboratory, Temple, $506 \mathrm{p}$.

[21] Arnold, J.G., Moriasi, D.N., Gassman, P.W., Abbaspour, K.C., White, M.J., Srinivasan, R., Santhi, C., Harmel, R.D., Van Griensven, A., Van Liew, M.W. and Kannan, M.K. (2012) Model Use, Calibration, and Validation. American Society of Agricultural and Biological Engineers, 55, 1491-1508. https://doi.org/10.13031/2013.42256

[22] Chilagane, N.A., Kashaigili, J.J. and Mutayoba, E. (2020) Historical and Future Spatial and Temporal Changes in Land Use and Land Cover in the Little Ruaha River Catchment, Tanzania. Journal of Geoscience and Environment Protection, 8, 76-96. https://doi.org/10.4236/gep.2020.82006

[23] Jiang, G., Zhang, F. and Kong, X. (2009) Determining Conversion Direction of Rural Residential Land Consolidation in Beijing Mountainous Areas. Transactions of the Chinese Society of Agricultural Engineering, 25, 214-221.

[24] Food and Agriculture Organization (2005) Digital Soil Map of the World and Derived Soil Properties of the World. Food and Agricultural Organization of the United Nations, Rome. 
[25] Zeray, L. (2007) Calibration and Validation of SWAT Hydrologic Model for Meki Watershed. Ethiopia, Conference of International Agricultural Research for Development, University of Kassel Wizenhausen and University of Gottingen, 9-11 October 2007, 1-5.

[26] Trucano, T.G., Swiler, L.P., Igusa, T., Oberkampf, W.L. and Pilch, M. (2006) Calibration Validation and Sensitivity Analysis. Reliability Engineering \& System Safety, 91, 1331-1357. https://doi.org/10.1016/j.ress.2005.11.031

[27] Abbaspour, K.C., Yang, J., Maximov, I., Siber, R., Bogner, K., Mieleitner, J. and Srinivasan, R. (2007) Modelling Hydrology and Water Quality in the Pre-Alpine/Alpine Thur Watershed Using SWAT. Journal of Hydrology, 333, 413-430.

https://doi.org/10.1016/j.jhydrol.2006.09.014

[28] Moriasi, D.N., Arnold, J.G., Van Liew, M.W., Bingner, R.L., Harmel, R.D. and Veith, T.L. (2007) Model Evaluation Guidelines for Systematic Quantification of Accuracy in Watershed Simulations. Transactions of the ASABE, 50, 885-900. https://doi.org/10.13031/2013.23153

[29] Nash, J.E. and Sutcliffe, J.V. (1970) River Flow Forecasting through Conceptual Models Part I-A Discussion of Principles. Journal of Hydrology, 10, 282-290. https://doi.org/10.1016/0022-1694(70)90255-6

[30] Van Liew, M.W., Arnold, J.G. and Garbrecht, J.D. (2003) Hydrologic Simulation on Agricultural Watersheds: Choosing between Two Models. Transactions of the ASAE, 46, 1539-1551. https://doi.org/10.13031/2013.15643

[31] Legates, D.R. and McCabe, G.J. (1999) Evaluating the Use of "Goodness-of-Fit" Measures in Hydrologic and Hydroclimatic Model Validation. Water Resources Research, 35, 233-241. https://doi.org/10.1029/1998WR900018

[32] Gupta, H.V., Sorooshian, S. and Yapo, P.O. (1999) Status of Automatic Calibration for Hydrologic Models: Comparison with Multilevel Expert Calibration. Journal of Hydrologic Engineering, 4, 135-143. https://doi.org/10.1061/(ASCE)1084-0699(1999)4:2(135)

[33] Yan, B., Fang, N.F., Zhang, P.C. and Shi, Z.H. (2013) Impacts of Land Use Change on Watershed Streamflow and Sediment Yield: An Assessment Using Hydrologic Modelling and Partial Least Squares Regression. Journal of Hydrology, 484, 26-37. https://doi.org/10.1016/j.jhydrol.2013.01.008

[34] Williams, J.R. (1975) Sediment-Yield Prediction with Universal Equation Using Runoff Energy Factor. In: Present and Prospective Technology for Predicting Sediment Yield and Sources, US Department of Agriculture, Agriculture Research Service, Washington DC, 244-252.

[35] Neitsch, S.L., Arnold, J.G. and Kiniry, J.R. (2005) Soil and Water Assessment Tool (SWAT) Theoretical Documentation. Blackland Research Center, Grassland, Soil and Water Research Laboratory, Agricultural Research Service, Temple.

[36] Kiersch, B. (2000) Land Use Impacts on Water Resources: A Literature Review. Land and Water Development Division, FAO, Rome, 72 p.

[37] Allan, J.D. (2004) Landscapes and Riverscapes: The Influence of Land Use on Stream Ecosystems. Annual Review of Ecology, Evolution, and Systematics, 35, 257-284. https://doi.org/10.1146/annurev.ecolsys.35.120202.110122

[38] Kashaigili, J.J. (2008) Impacts of Land-Use and Land-Cover Changes on Flow Regimes of the Usangu Wetland and the Great Ruaha River, Tanzania. Physics and Chemistry of the Earth, Parts $A / B / C, 33,640-647$.

https://doi.org/10.1016/j.pce.2008.06.014

[39] Näschen, K., Diekkrüger, B., Evers, M., Höllermann, B., Steinbach, S. and Thonfeld, 
F. (2019) The Impact of Land Use/Land Cover Change (LULCC) on Water Resources in a Tropical Catchment in Tanzania under Different Climate Change Scenarios. Sustainability, 11, 7083. https://doi.org/10.3390/su11247083

[40] Bruijnzeel, L.A. (1990) Hydrology of Moist Tropical Forests and Effects of Conversion: A State of Knowledge Review. Hydrology of Moist Tropical Forests and Effects of Conversion: A State of Knowledge Review, 104, 185-288.

[41] Kashaigili, J.J. and Majaliwa, A.M. (2013) Intergrated Assessment of Land Use Land Cover Changes on Hydrological Regime of the Malagarasi River Catchment in Tanzania. Journal of Physics and Chemistry of the Earth, 35, 730-741. https://doi.org/10.1016/j.pce.2010.07.030

[42] Haile, G.E. and Assefa, M.M. (2012) The Impact of Land Use Changes on the Hydrology of the Angereb Watershed, Ethiopia. International Journal of Water Sciences, 132, 53-62.

[43] Balthazar, V., Vanacker, V., Molina, A. and Lambin, E.F. (2015) Impacts of Forest Cover Change on Ecosystem Services in High Andean Mountains. Ecological Indicators, 48, 63-75. https://doi.org/10.1016/j.ecolind.2014.07.043 


\section{Appendix}

Appendix 1. Land Use Land Cover Change Analysis 1990-2015 (Chilagane, 2020)

\begin{tabular}{|c|c|c|c|c|c|c|c|c|c|c|c|c|c|c|c|}
\hline \multirow{2}{*}{$\begin{array}{l}\text { Years } \\
\text { LULC }\end{array}$} & \multicolumn{2}{|c|}{1990} & \multicolumn{2}{|l|}{2005} & \multicolumn{2}{|c|}{2015} & \multicolumn{3}{|c|}{$1990-2005$} & \multicolumn{3}{|c|}{$2005-2015$} & \multicolumn{3}{|c|}{$1990-2015$} \\
\hline & $\begin{array}{c}\text { Cover } \\
\text { area (ha) }\end{array}$ & $\%$ & $\begin{array}{c}\text { Cover } \\
\text { area }(h a)\end{array}$ & $\%$ & $\begin{array}{c}\text { Cover } \\
\text { area (ha) }\end{array}$ & $\%$ & $\begin{array}{c}\text { Change } \\
\text { area (ha) }\end{array}$ & $\begin{array}{c}\% \\
\text { Change }\end{array}$ & $\begin{array}{l}\text { Annual rate } \\
\text { of change }\end{array}$ & $\begin{array}{l}\text { Change } \\
\text { area (ha) }\end{array}$ & $\%$ Change & $\begin{array}{c}\text { Annual rate } \\
\text { of change }\end{array}$ & $\begin{array}{l}\text { Change } \\
\text { area (ha) }\end{array}$ & $\begin{array}{c}\% \\
\text { Change }\end{array}$ & $\begin{array}{c}\text { Annual rate } \\
\text { of change }\end{array}$ \\
\hline FR & 39,872 & 6.26 & 22,957 & 3.6 & 15950 & 2.5 & -16915 & -42.42 & -1127.67 & -7007 & -30.52 & -700.70 & -23922 & -60.00 & -956.88 \\
\hline PL & 20,632 & 3.24 & 34,068 & 5.35 & 24285 & 3.81 & 13436 & +65.12 & +895.73 & -9783 & -28.72 & -978.30 & +3653 & +17.71 & 146.12 \\
\hline $\mathrm{RF}$ & 5878 & 0.92 & 2746 & 0.43 & 1083 & 0.17 & -3132 & -53.28 & -208.80 & -1663 & -60.56 & -166.30 & -4795 & -81.58 & -191.80 \\
\hline WTR & 1752 & 0.28 & 1202 & 0.19 & 657 & 0.1 & -550 & -31.39 & -36.67 & -545 & -45.34 & -54.50 & -1095 & -62.50 & -43.80 \\
\hline WET & 19,157 & 3.01 & 11,785 & 1.85 & 5622 & 0.88 & -7372 & -38.48 & -491.47 & -6163 & -52.30 & -616.30 & -13535 & -70.65 & -541.40 \\
\hline WD & 109,692 & 17.22 & 72,809 & 11.43 & 58554 & 9.19 & -36883 & -33.62 & -2458.87 & -14255 & -19.58 & -1425.50 & -51138 & -46.62 & -2045.52 \\
\hline WR & 60,288 & 9.46 & 75,121 & 11.79 & 43767 & 6.87 & +14833 & +24.60 & +988.87 & -31354 & -41.74 & -3135.40 & -16521 & -27.40 & -660.84 \\
\hline $\mathrm{CW}$ & 57,368 & 9.01 & 54,517 & 8.56 & 55300 & 8.68 & -2851 & -4.97 & -190.07 & +783 & +1.44 & +78.30 & -2068 & -3.60 & -82.72 \\
\hline GR & 118,784 & 18.65 & 129,797 & 20.38 & 148795 & 23.36 & +11013 & +9.27 & +734.20 & +18998 & +14.64 & +1899.80 & +30011 & +25.27 & +1200.44 \\
\hline BS & 87,394 & 13.72 & 111,284 & 17.47 & 125759 & 19.74 & +23890 & +27.34 & +1592.67 & +14475 & +13.01 & +1447.50 & +38365 & +43.90 & +1534.60 \\
\hline CLT & 106,782 & 16.76 & 109,047 & 17.12 & 143470 & 22.52 & +2265 & +2.12 & +151.00 & +34423 & +31.57 & +3442.30 & +36688 & +34.36 & +1467.52 \\
\hline BLT & 9408 & 1.48 & 11,674 & 1.83 & 13765 & 2.16 & +2266 & +24.09 & +151.07 & +2091 & +17.91 & +209.10 & +4357 & +46.31 & +174.28 \\
\hline Total & 637,007 & 100 & 637,007 & 100 & 637007 & 100 & & & & & & & & & \\
\hline
\end{tabular}

FR: Forest; PL: Plantation; RF: Riverine forest; WTR: Water; WET: Wetland; WD: Woodland; WR: Wooded rock; CW: Cultivated woodland; GR: Grassland; BS: Bushland; CLT: Cultivated land; BLT: Built up area

\section{Appendix 2. Predicted Land Use/Cover Based on CA-Markov Model (Chilagane, 2020)}

\begin{tabular}{ccc}
\hline LULC & \multicolumn{2}{c}{ 2040 } \\
\cline { 2 - 3 } Forest & Area (Ha) & Coverage (\%) \\
Plantation & 11,936 & 1.87 \\
Riverine forest & 22,950 & 3.60 \\
Water & 461 & 0.07 \\
Wetland & 211 & 0.03 \\
Woodland & 3183 & 0.50 \\
Wooded rock & 50,158 & 7.87 \\
Cultivated woodland & 35,387 & 5.56 \\
Grassland & 49,901 & 7.83 \\
Bushland & 160,422 & 25.18 \\
Cultivated land & 130,023 & 20.41 \\
Built up & 158,132 & 24.82 \\
Total & 14,242 & 2.24 \\
\hline
\end{tabular}

